\title{
Synthesis, Characterization and Cytotoxicity Evaluation of New Heterocyclic Compounds with Oxazole Ring Containing 4-(Phenylsulfonyl)phenyl Moiety
}

\author{
THEODORA VENERA APOSTOL ${ }^{1}$, STEFANIA FELICIA BARBUCEANU ${ }^{*}$, LAURA ILEANA SOCEA ${ }^{1}$, CONSTANTIN DRAGHICI ${ }^{2}$, \\ GABRIEL SARAMET ${ }^{3}$, LUCIAN ISCRULESCU ${ }^{1}$, OCTAVIAN TUDOREL OLARU ${ }^{4}$ \\ ${ }^{1}$ Carol Davila University of Medicine and Pharmacy, Faculty of Pharmacy, Organic Chemistry Department, 6 Traian Vuia Str., \\ 020956, Bucharest, Romania \\ ${ }^{2}$ Military Medical Scientific Research Center, 24-28 Gr. Cobalcescu Str., 010195, Bucharest, Romania \\ ${ }^{3}$ Carol Davila University of Medicine and Pharmacy, Faculty of Pharmacy, Pharmaceutical Technology and Biopharmacy Department, \\ 6 Traian Vuia Str., 020956, Bucharest, Romania \\ ${ }^{4}$ Carol Davila University of Medicine and Pharmacy, Faculty of Pharmacy, Pharmaceutical Botany and Cell Biology Department, \\ 6 Traian Vuia Str., 020956, Bucharest, Romania
}

\begin{abstract}
The paper presents the synthesis, characterization and cytotoxicity assessment of five organic compounds containing 4-(phenylsulfonyl)phenyl fragment in the molecule, namely of three acyclic precursors derived from phenylalanine (from $N$-acyl- $\alpha$-amino acids, $N$-acyl- $\alpha$-amino acyl chlorides and $N$-acyl- $\alpha$-amino ketones class) and of the cyclization products: a 1,3-oxazol-5(4H)-one and, respectively, a 1,3-oxazole substituted in position 5 with the $p$-tolyl group. The synthesized compounds were characterized by spectral methods (UVVis, FT-IR, ${ }^{1} \mathrm{H}-\mathrm{NMR},{ }^{13} \mathrm{C}-\mathrm{NMR}$, and MS) and elemental analysis, which confirmed their structures. For the determination of the purity of the new compounds, the RP-HPLC method was used. In view of the therapeutic potential of the newly synthesized compounds, we evaluated their toxicological profile using the Daphnia magna bioassay.
\end{abstract}

Keywords: $N$-acyl- $\alpha$-amino acid, 1,3-oxazol-5(4H)-one, $N$-acyl- $\alpha$-amino ketone, 1,3-oxazole, cytotoxic effect

The study of scientific literature revealed the fact that five-membered heterocyclic compounds from 1,3-oxazol5(4H)-one and 1,3-oxazole class, and their acyclic precursors from $N$-acyl- $\alpha$-amino acid, $N$-acyl- $\alpha$-amino acid chloride and $\mathrm{N}$-acyl-á-amino ketone class present a particular interest in synthetic organic chemistry. With the exception of $N$-acyl- $\alpha$-amino acyl chlorides - which are known to have a high reactivity - these compounds have attracted the attention due to importance in the field of medicinal chemistry because of their diverse biological activities.

In this regard, the 1,3-oxazole ring is found in the structure of various biologically active natural products, such as Martefragin A (a potentinhibitor of lipid peroxidation) [1], Diazonamide A (an anticancer agent that inhibits tubulin polymerization) [2], Virginiamycin $\mathrm{M}_{2}$ Madumycin II, Griseoviridin (representative examples of the group A streptogramin antibiotics) [3], Calyculin A (a potent, selective serine-threonine phosphatase inhibitor) [4], Hennoxazole $A$ (active against herpex simplex virus type 1 and with peripheral analgesic activity) [1], Muscoride A (an antibacterial agent) [5], Ulapualide A (with antifungal effect) [1], Texaline (an antimycobacterial alkaloid) [6]. Also, members of 1,3-oxazole class are active substances in several modern pharmaceuticals, including Oxaprozin (a non-opioid analgesic, antipyretic, and non-steroidal antiinflammatory drug) [7], Aleglitazar, Farglitazar, Muraglitazar (dual PPAR $\alpha / \gamma$ agonists from glitazar class used in treatment of type 2 diabetes) [8], Ditazole (an inhibitor of platelet aggregation) [9], Mubritinib (a tyrosine kinase inhibitor) [10], Sulfamoxole (a chemotherapeutic agent from the sulfonamides group with antibacterial activity) [11], Azumolene (which exhibit skeletal muscle relaxant action) [12].
Among oxazole derivatives, the 5-hydroxy-substituted 1,3-oxazoles derived from $N$-acyl- $\alpha$-amino acids (the aromatic enol form) exist in their corresponding nonaromatic oxo form: the saturated 1,3-oxazol-5(4H)-ones, classically referred to as saturated azlactones. Some representatives of this class have been reported to possess antiviral [13], antitumoral [14], cytotoxic [15], plant grow th regulating activity [16].

Open-chain intermediates from $\mathrm{N}$-acyl- $\alpha$-amino acid and $N$-acyl- $\alpha$-amino ketone classes are also known in the literature as active substances with significant biological properties. Thus, the $\mathrm{N}$-acyl derivatives of amino acids are used as mucolytic (e.g. N-Acetyl cysteine) [17], antioxidant (e.g. N-Acetyl cysteine) [18], anticancer (e.g. Methotrexate, Aminopterin, Ubenimex, Pralatrexate) [19], antihypertensive (e.g. ACEIs proline derivatives: Captopril, Lisinopril, Enalapril) [20], antianemic (e. g. Folic acid) [21], vasoconstrictor (e. g. Angiotensin II) [22], anti-ulcer drugs (e. g. Benzotript) [23] etc. Moreover, some $\mathrm{N}$-acyl- $\alpha$-amino acids are specific antidotes in poisoning with paracetamol, carbon tetrachloride (e.g. $\mathrm{N}$-acetyl cysteine) [24], antifolates and are also administered in methanol acute intoxication to enhance formic acid metabolism (e. g. Folinic acid) [25].

The $\mathrm{N}$-acyl- $\alpha$-amino ketones, as well as other 2-aza1,4-butandiones, have been described in the literature as peptidomimetic inhibitors of proteases, compounds of this class being used for antiviral (e.g. Rupintrivir) [26], antithrombotic [27], anti-inflammatory action [28].

In addition, biological investigations in the diaryl sulfone class have also highlights that many derivatives exhibit multiple therapeutic properties, such as antimicrobial, antimalarial, anticancer, antioxidant effect [29] etc. Some of these active pharmaceutical ingredients (e.g. 
Acedapsone, Dapsone, Glucosulfone, Solasulfone, Sulfoxone, Thiazosulfone) are part of the composition of medicinal products used to treat leprosy, malaria, tuberculosis, and other infectious diseases. Based on these literature data, the diaryl sulfonyl substituent has been included in the structure of diverse organic compounds with potential biological activities [15, 16, 30-32].

In view of these literature data and taking into account the previous research in the synthesis of derivatives which contain a fragment derived from a diaryl sulfone $[15,16$, 33], we pursued the union of two pharmacophore centers, namely a heterocycle (with 1,3-oxazol-5(4H)-one or 1,3oxazole ring) and an acyclic precursor (from $\mathrm{N}$-acyl- $\alpha$ amino acid, $\mathrm{N}$-acyl- $\alpha$-amino acyl chloride or $\mathrm{N}$-acyl- $\alpha$ amino ketone class), respectively, with a 4(phenylsulfonyl)phenyl moiety (a common structural element in all these newly synthesized compounds), in a single structure in order to obtain new bioactive substances and to investigate preliminary aspects of the structureactivity relationship. For this purpose, the novel synthesized compounds were tested for cytotoxic activity using Daphnia magna bioassay. Among other alternative screening assays, this method is simple, rapid, and can predict the biological effect [34-41].

\section{Experimental part \\ Chemistry}

All reactants and solvents were purchased commercially with highest purity and were used without further purification. The melting points were determined on a Böetius apparatus and are uncorrected. The UV-Vis spectra were recorded in methanolic solution $\left(\approx 2.5 \times 10^{-5} \mathrm{M}\right)$ on an Analytik Jena AG Specord 40 spectrophotometer. The FTIR spectra were registered in $\mathrm{KBr}$ pellets on a Bruker Vertex 70 spectrometer; the intensity of IR absorption bands are given as: very strong (vs), strong (s), medium (m), and weak $(w)$. The NMR spectra were recorded on a Varian Gemini 300BB spectrometer at $300 \mathrm{MHz}$ for ${ }^{1} \mathrm{H}-\mathrm{NMR}$ and $75 \mathrm{MHz}$ for ${ }^{13} \mathrm{C}$-NMR using DMSO-d $\mathrm{d}_{6}$ or $\mathrm{CDCl}_{3}$ as solvents; the chemical shifts $(\delta)$ are reported in parts per million (ppm) relative to tetramethylsilane (TMS) as internal standard and the coupling constants $(J)$ are expressed in hertz $(\mathrm{Hz})$. In the ${ }^{1} \mathrm{H}$-NMR spectra, the following abbreviations for multiplicities and descriptors of signals were used: $s=$ singlet, $d=$ doublet, $d d=$ doublet of doublets, $\mathrm{ddd}=$ doublet of doublets of doublets, $\mathrm{t}=$ triplet, $\mathrm{td}=$ triplet of doublets, $\mathrm{t}=$ = triplet of triplets, $\mathrm{m}=$ multiplet; $\mathrm{b}=$ broad signal. The GC-EI-MS analysis was carried out using a Fisons Instruments GC 8000 with an electron impact quadrupole, MD 800 mass spectrometer detector. A fused-silica capillary column coated with poly $(5 \%$ diphenyl/95\% dimethyl siloxane) (SLB-5ms, L x I.D. $30 \mathrm{~m}$ $x 0.32 \mathrm{~mm}, d_{f} 0.25 \mu \mathrm{m}$ ) was used. The carrier gas (helium) flow rate was $2 \mathrm{~mL} / \mathrm{min}$ and $1 \mu \mathrm{L}$ sample solution in dichloromethane was injected. The purity of the new compounds was evaluated by RP-HPLC using a Beckman System Gold 126 liquid chromatograph, equipped with a System Gold 166 UV-Vis detector, a non-polar chromatography column (type LiChrosorb RP-18, $5 \mu \mathrm{m}$ particle size, L x I.D. $25 \mathrm{~cm} \times 4 \mathrm{~mm}$ ) and a Rheodyne injection system; the mobile phase was a mixture of methanol - water in different proportions, with a flow rate of $1 \mathrm{~mL} / \mathrm{min}$. The retention time $\left(t_{R}\right)$ of analyzed compounds in minutes is reported. The contents of $\mathrm{C}, \mathrm{H}, \mathrm{N}$, and S w ere determined using a Costech ECS 4010 micro elemental analyzer; results were found within the $\pm 0.4 \%$ of theoretical values.

\section{Synthesis and characterization of compounds}

The sequence of reactions used for synthesis of the title compounds are presented in scheme 1. Thus, the known precursor, acyl chloride 2 , is obtained by the reaction of the corresponding carboxylic acid 1 with thionyl dichloride. The $\mathrm{N}$-acyl phenylalanine $\mathbf{3}$ was prepared by the Steiger $\mathrm{N}$ acylation of phenylalanine with acyl chloride 2 . Further, the compound $\mathbf{3}$ was cyclized in the presence of ethyl chloroformate, and 4-methylmorpholine to the corresponding saturated azlactone 4 . Also, the $\mathrm{N}$-acylated

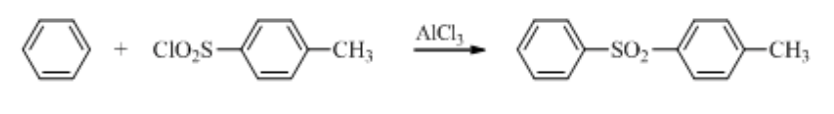

$\mathrm{CrO}_{3} / \mathrm{CH}_{3} \mathrm{COOH}$
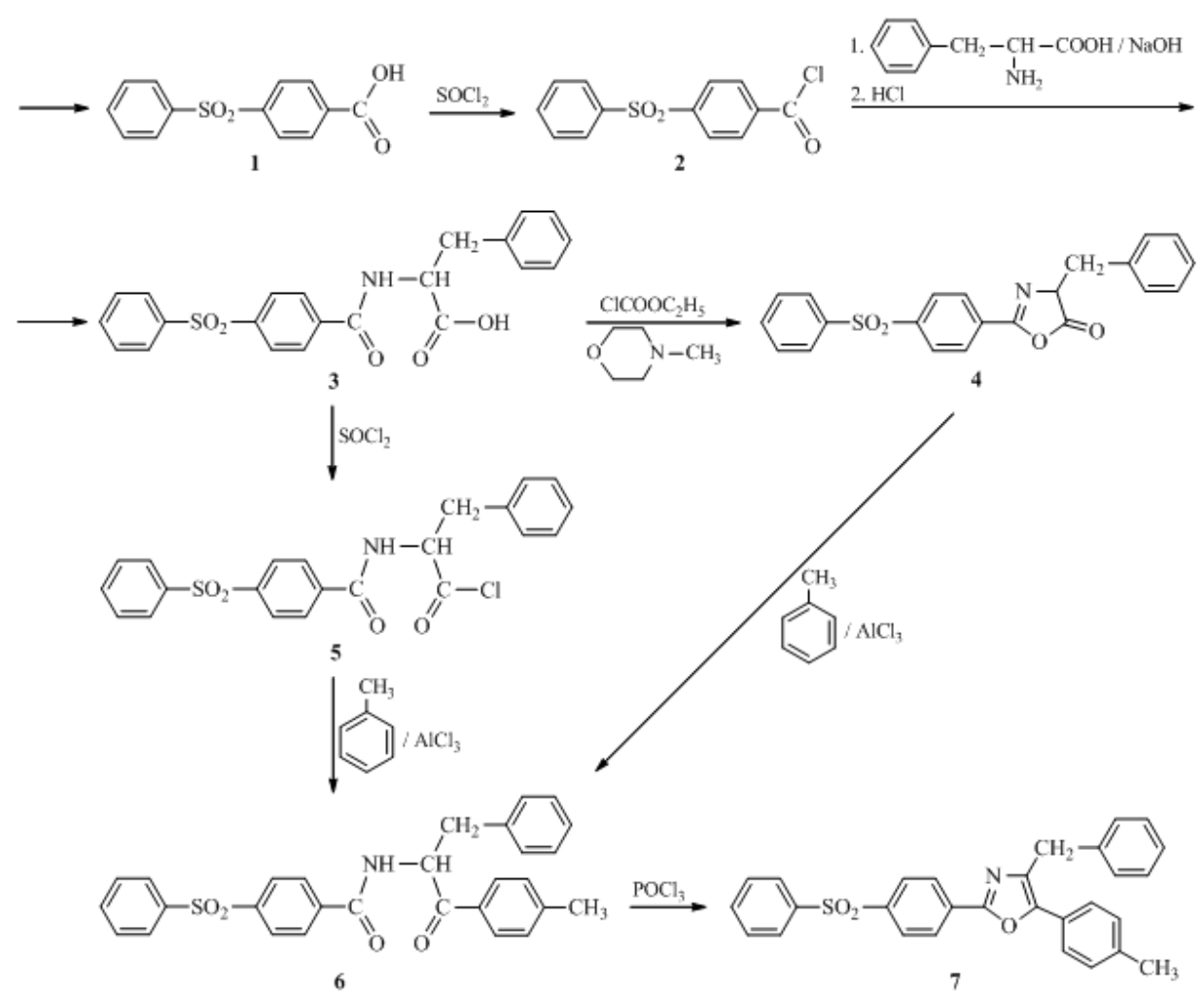

Scheme 1. Synthetic route of the title compounds 
phenylalanine was refluxed in thionyl dichloride to obtain the corresponding acyl chloride $\mathbf{5}$. The Friedel-Crafts reaction of anhydrous toluene with 1,3-oxazol-5(4H)-one 4 and $\mathrm{N}$-acyl phenylalanyl chloride $\mathbf{5}$, respectively, in the presence of anhydrous aluminium chloride, produced the corresponding $N$-acyl- $\alpha$-amino ketone 6 . This intermediate was converted by Robinson-Gabriel synthesis into 2,4,5trisubstituted 1,3-oxazole 7 using phosphoryl trichloride as cyclodehydrating agent. The chemical structures of all synthesized compounds 3-7 were proved by FT-IR, UV-Vis, MS, ${ }^{1 H} \mathrm{H}-\mathrm{NMR},{ }^{13} \mathrm{C}-\mathrm{NMR}$ spectra, and elemental analysis.

Synthesis of 3-phenyl-2-[4-(phenylsulfonyl)benzamido] propanoic acid $\mathbf{3}$

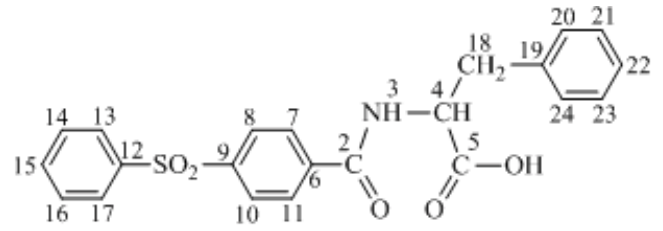

Fig. 1. Structure of compound $\mathbf{3}$ with atom numbering (for NMR assignments)

Phenylalanine $(3.30 \mathrm{~g}, 20 \mathrm{mmol})$ was dissolved in 20 $\mathrm{mL}$ of $1 \mathrm{~N}$ sodium hydroxide solution. The formed solution was cooled to $0-5^{\circ} \mathrm{C}$ in a ice bath and then two solutions were added simultaneously dropwise under continuous stirring for $30 \mathrm{~min}$, as follows: a solution of crude 4(phenylsulfonyl) benzoyl chloride $2(5.61 \mathrm{~g}, 20 \mathrm{mmol}$ ) in 45 $\mathrm{mL}$ anhydrous dichloromethane and $10 \mathrm{~mL}$ of $2 \mathrm{~N}$ sodium hydroxide solution, respectively. After $1 \mathrm{~h}$ of stirring at room temperature, the aqueous layer was separated and then acidified with $2 \mathrm{~N}$ hydrochloric acid. The obtained precipitate was filtered off, washed with water, dried, and then recrystallized from water as white needle-shaped crystals; yield $=93 \%(7.62 \mathrm{~g}) ; \mathrm{m} . \mathrm{p} .=189-191^{\circ} \mathrm{C}$.

UV-Vis $\left(\mathrm{CH}_{3} \mathrm{OH}, \delta \mathrm{nm}\right)(\mathrm{lg} \varepsilon): 202.6(4.47) ; 244.1$ (4.11).

FT-IR ( $\left.\mathrm{KBr}^{3} v \mathrm{~cm}^{-1}\right): 3348 \mathrm{vs} ; 3084 \mathrm{~m} ; 3066 \mathrm{~m} ; 3032 \mathrm{~m}$; 2969s; 2932s; 2906s; 2792m; 2746m; 2713m; 2667m; 2587m; 1748vs; 1642vs; 1601s; 1568m; 1540vs; 1497m; 1446s; 1318s; 1309vs; 1296vs; 1152vs; 860m.

${ }^{1} \mathrm{H}-\mathrm{NMR}$ (DMSO-d $\left.{ }^{\prime} \delta \mathrm{ppm}, J \mathrm{~Hz}\right): 3.04$ (dd, 14.0, 10.7, $1 \mathrm{H}, \mathrm{H}-18$ ); 3.21 (dd, $14.0,4.7,1 \mathrm{H}, \mathrm{H}-18) ; 4.64$ (ddd, 10.7, $8.2,4.7,1 \mathrm{H}, \mathrm{H}-4) ; 7.16$ (td, 7.0, 1.6, $1 \mathrm{H}, \mathrm{H}-22) ; 7.26$ (m, 4H, $\mathrm{H}-20, \mathrm{H}-21, \mathrm{H}-23, \mathrm{H}-24) ; 7.63$ (bt, 7.2, 2H, H-14, H-16); 7.71 $(\mathrm{tt}, 7.2,1.6,1 \mathrm{H}, \mathrm{H}-15) ; 7.96(\mathrm{~d}, 8.2,2 \mathrm{H}, \mathrm{H}-7, \mathrm{H}-11) ; 7.98$ (dd, 7.2, 1.6, 2H, H-13, H-17); 8.06 (d, 8.2, 2H, H-8, H-10); 8.98 (d, 8.2, $1 \mathrm{H}, \mathrm{NH})$.

${ }^{13} \mathrm{C}-\mathrm{NMR}$ (DMSO-d ${ }_{6,} \delta \mathrm{ppm}$ ): 36.35 (C-18); 54.38 (C-4); 126.49 (C-22); 127.56 (C-13, C-17); 127.62 (C-8, C-10); 128.30 (C-21, C-23); 128.74 (C-7, C-11); 129.10 (C-20, C24); 129.92 (C-14, C-16); 134.05 (C-15); 138.04 (C-6); 138.62 (C-19); 140.75 (C-12); 143.42 (C-9); 165.20 (C-2); 172.87 (C-5).

RP-HPLC $\left(\mathrm{CH}_{3} \mathrm{OH}: \mathrm{H}_{2} \mathrm{O}=30: 70,1 \mathrm{~mL} / \mathrm{min}, 250 \mathrm{~nm}\right)$ : purity $=99.99 \% ; t_{\mathrm{m}}=3.34 \mathrm{~min}$.

Anal. (\%): Calcd. for $\mathrm{C}_{22} \mathrm{H}_{19} \mathrm{NO}_{5} \mathrm{~S}(409.45 \mathrm{~g} / \mathrm{mol}): \mathrm{C}, 64.53$; $H, 4.68 ; \mathrm{N}, 3.42$; S, 7.83. Found: $\mathrm{C}, 64.59 ; \mathrm{H}, 4.67$; N, 3.41; S, 7.80 .

Synthesis of 4-benzyl-2-[4-(phenylsulfonyl)phenyl] oxazol$5(4 H)$-one 4

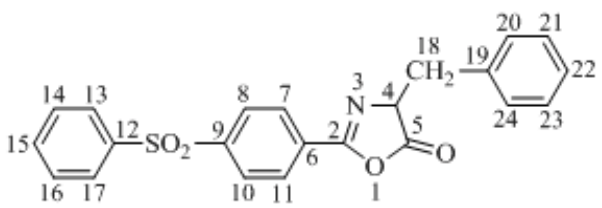

Fig. 2. Structure of compound $\mathbf{4}$ with atom numbering (for NMR assignments)
3-Phenyl-2-[4-(phenylsulfonyl) benzamido]propanoic acid $3(4.30 \mathrm{~g}, 10.5 \mathrm{mmol})$ and 4-methylmorpholine (1.15 $\mathrm{mL}, 10.5 \mathrm{mmol}$ ) were added under stirring into $50 \mathrm{~mL}$ anhydrous dichloromethane at room temperature. An equimolar quantity of ethyl chloroformate $(1 \mathrm{~mL})$ was then added dropwise to the heterogeneous reaction mixture. The formed solution was magnetically stirred for $30 \mathrm{~min}$ at ambient temperature and then poured over $100 \mathrm{~mL}$ cold water. The organic layer was separated and washed with $5 \%$ sodium hydrogen carbonate solution and then with water. After drying over anhydrous magnesium sulphate, the solvent was removed by distillation under reduced pressure. The solid productwas purified by recrystallization from cyclohexane as white crystals; yield $=94 \%(3.86 \mathrm{~g})$; m.p. $=119-121^{\circ} \mathrm{C}$.

UV-Vis $\left(\mathrm{CH}_{3} \mathrm{OH}, \lambda \mathrm{nm}\right)(\mathrm{lg} \varepsilon): 202.6(4.48) ; 244.9$ (4.15). FT-IR ( $\left.\mathrm{KBr}^{3} \vee \mathrm{cm}^{-1}\right)$ : 3088m; 3063m; 3031m; 2922vs; 2849s; 1823vs; 1651vs; 1599m; 1581m; 1572m; 1495s; 1448vs; 1325vs; 1295vs; 1270s; 1162vs; 1045vs; 848s.

${ }^{1} \mathrm{H}-\mathrm{NMR}\left(\mathrm{CDCl}_{2}, \delta \mathrm{ppm}\right.$, J Hz): 3.18 (dd, 14.0, 6.6, $1 \mathrm{H}, \mathrm{H}-$ 18); 3.38 (dd, 14.0, 4.9, $1 \mathrm{H}, \mathrm{H}-18$ ); 4.72 (dd, 6.6, 4.9, $1 \mathrm{H}, \mathrm{H}$ 4); $7.20-7.25(\mathrm{~m}, 5 \mathrm{H}, \mathrm{H}-2 \mathrm{O}, \mathrm{H}-21, \mathrm{H}-22, \mathrm{H}-23, \mathrm{H}-24)$; 7.53 (t, 7.4, 2H, H-14, H-16); 7.61 (tt, 7.4, 1.6, 1H, H-15); 7.96 (dd, 7.4, 1.6, 2H, H-13, H-17); 8.02 (s, 4H, H-7, H-8, H-10, H11).

${ }^{13} \mathrm{C}-\mathrm{NMR}\left(\mathrm{CDCl}_{3}, \delta \mathrm{ppm}\right): 37.27$ (C-18); 66.79 (C-4); 127.44 (C-22); 127.99 (C-8, C-10); 128.09 (C-13, C-17, C21, C-23); 128.78 (C-7, C-11); 129.58 (C-14, C-16, C-20, C24); 130.14 (C-6); 133.76 (C-15); 134.94 (C-19); 140.86 (C-12); 145.49 (C-9); 160.47 (C-2); 176.73 (C-5).

GC-El-MS ( $/ \mathrm{m} / \mathrm{z}$, rel. abund. \%): 347 (74.29) [M-CO $]^{+\times}$; 205 (42.14) [ $\left.\mathrm{C}_{6} \mathrm{H}_{\mathrm{CNCHCHC}} \mathrm{H}_{5}\right]^{+\times} ; 130$ (100, BP) [ $\left.\mathrm{C}_{6} \mathrm{H}_{5} \mathrm{CHCCO}\right]^{+\times} ; 125(15.36)\left[\mathrm{C}^{5} \mathrm{H}_{5} \mathrm{SO}^{+}\right.$; 103 (23.93) $\left[\mathrm{C}_{6} \mathrm{H}_{5}^{5} \mathrm{CHCH}\right]^{+} ; 91$ (16.43) $\left[\mathrm{C}_{6} \mathrm{H}_{5} \mathrm{CH}_{2}\right]^{+} ; 77$ (30.71) $\left[\mathrm{C}_{6} \mathrm{H}_{5}\right]^{+}$; $51^{6}$ (9.64) $\left[\mathrm{C}_{4} \mathrm{H}_{3}\right]^{+} ; t=50.03^{6}$ min.

RP-HPLC $\left(\mathrm{CH}_{3} \mathrm{OH}: \mathrm{H}_{2} \mathrm{O}=60: 40,1 \mathrm{~mL} / \mathrm{min}, 250 \mathrm{~nm}\right)$ : purity $=92.03 \% ; t=4.78 \mathrm{~min}$.

Anal. (\%): Calcd. for $\mathrm{C}_{2} \mathrm{H}_{1} \mathrm{NO} S(391.44 \mathrm{~g} / \mathrm{mol}): \mathrm{C}, 67.50$; $H, 4.38 ; N, 3.58 ; S$, 8.19. Found: C, 67.56; H, 4.37; N, 3.57; S, 8.21 .

\section{Synthesis of 3-phenyl-2-[4-(phenylsulfonyl)benzamido]} propanoyl chloride 5

3-Phenyl-2-[4-(phenylsulfonyl) benzamido]propanoic acid $\mathbf{3}(2.25 \mathrm{~g}, 5.5 \mathrm{mmol})$ was refluxed with a 25 -fold molar excess of thionyl dichloride $(10 \mathrm{~mL})$ until emission of sulfur dioxide and hydrogen chloride gas ceased. The unreacted thionyl dichloride was removed to dryness by distillation under reduced pressure. The crude product obtained as yellow crystals was used without further purification; yield $=98 \%(2.31 \mathrm{~g}) ; \mathrm{m} . \mathrm{p} .=88-89^{\circ} \mathrm{C}$.

FT-IR $\left(\mathrm{KBr}, v \mathrm{~cm}^{-1}\right)$ : 3437s; 3090m; 3064m; 3032m; 2967m; 2946w; 2841w; 1823s; 1794s; 1651vs; 1597m; $1570 \mathrm{~m} ; 1517 \mathrm{~m} ; 1495 \mathrm{~m} ; 1447 \mathrm{~s} ; 1323 \mathrm{vs} ; 1309 \mathrm{vs} ; 1293 \mathrm{vs} ;$ 1159vs; $890 \mathrm{~m} ; 850 \mathrm{~m}$.

Synthesis of N-(1-oxo-3-phenyl-1-p-tolylpropan-2-yl)-4(phenylsulfonyl)benzamide 6

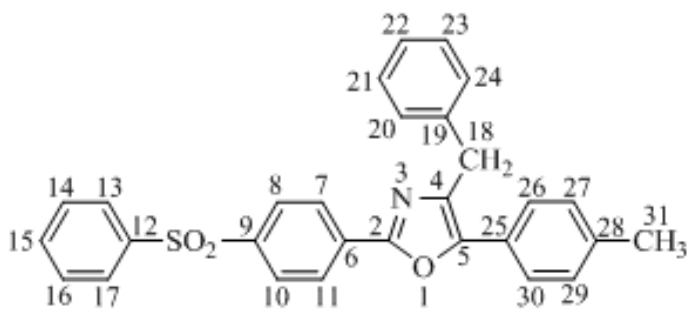

Fig. 3. Structure of compound 6 with atom numbering (for NMR assignments) 
Method 1. Anhydrous aluminium chloride $(2.00 \mathrm{~g}, 15$ $\mathrm{mmol}$ ) was added portionwise under stirring at room temperature to the crude 4-benzyl-2-[4-(phenylsulfonyl) phenyl]oxazol-5(4H)-one 4 (1.96 g, $5 \mathrm{mmol}$ ) in a 47-fold molar excess of anhydrous toluene $(25 \mathrm{~mL})$. The reaction mixture was stirred for $20 \mathrm{~h}$ and then poured over $100 \mathrm{~mL}$ ice-water, acidulated with $5 \mathrm{~mL}$ concentrated hydrochloric acid. The precipitate of crude product was filtered off and washed with cold water and a cool mixture of water ethanol $(1: 1, v / v)$. The layers of the filtrate were separated and the aqueous phase was extracted twice with $15 \mathrm{~mL}$ dichloromethane. The combined organic layers were washed with water, dried (over $\mathrm{Na}_{2} \mathrm{SO}_{4}$ ), and evaporated under reduced pressure, leaving a second fraction of crude product. Recrystallization from ethanol supplied the title product as colourless crystals; yield $=91 \%(2.20 \mathrm{~g})$.

Method 2. A 3-fold molar excess of anhydrous aluminium chloride $(2.00 \mathrm{~g}, 15 \mathrm{mmol})$ was added portionwise under stirring at room temperature to the crude 3-phenyl-2-[4(phenylsulfonyl)benzamido] propanoyl chloride 5 ( $2.14 \mathrm{~g}$, $5 \mathrm{mmol}$ ) in $25 \mathrm{~mL}$ of anhydrous toluene (used as solvent and reactant). Stirring was continued for $20 \mathrm{~h}$ until the evolution of hydrochloric acid ceased and then the reaction mass was poured over $100 \mathrm{~mL}$ mixture of acidulated (with $5 \mathrm{~mL} 37 \% \mathrm{HCl}$ ) ice-water. After extraction in dichloromethane, the organic layer was washed with $5 \%$ sodium hydrogen carbonate solution, then with water and dried over anhydrous magnesium sulphate. Evaporation of the solvent mixture under reduced pressure and recrystallization of crude product from ethanol led to colourless solid; yield $=77 \%(1.86 \mathrm{~g})$;

m.p. $=185-187^{\circ} \mathrm{C}$.

UV-Vis ( $\left.\mathrm{CH}_{3} \mathrm{OH}, \lambda \mathrm{nm}\right)(\mathrm{lg} \varepsilon): 203.5$ (4.47); 250.2 (4.14).

FT-IR $\left(\mathrm{KBr}, \mathrm{cm}^{-1}\right)$ : 3357vs; 3090m; 3061m; 3033m; $2966 \mathrm{~m} ; 2920 \mathrm{~m}$; 2851m; 1670vs; 1652vs; 1603s; 1570s; 1533vs; 1483m; 1447s; 1323vs; 1310vs; 1294vs; 1163vs; $853 \mathrm{~m}$.

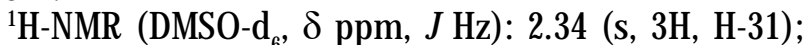
3.01 (dd, 14.0, 9.9, 1H, H-18); 3.19 (dd, 14.0, 4.7, $1 \mathrm{H}, \mathrm{H}-18$ ); 5.66 (ddd, 9.9, 8.2, 4.7, 1H, H-4); 7.15 (bt, 7.4, 1H, H-22); 7.24 (t, 7.4, 2H, H-21, H-23); 7.32 (d, 8.2, 2H, H-27, H-29); $7.33(\mathrm{~m}, 2 \mathrm{H}, \mathrm{H}-20, \mathrm{H}-24) ; 7.62(\mathrm{t}, 7.4,2 \mathrm{H}, \mathrm{H}-14, \mathrm{H}-16) ; 7.70$ (bt, 7.4, $1 \mathrm{H}, \mathrm{H}-15) ; 7.92$ (d, 8.5, 2H, H-7, H-11); 7.93 (d, 8.2, $2 \mathrm{H}, \mathrm{H}-26, \mathrm{H}-30$ ); 7.97 (d, 7.4, 2H, H-13, H-17); 8.04 (d, 8.5, $2 \mathrm{H}, \mathrm{H}-8, \mathrm{H}-10) ; 9.20$ (d, 8.2, $1 \mathrm{H}, \mathrm{NH})$.

${ }^{13} \mathrm{C}$-NMR (DMSO-d,$\delta \mathrm{ppm}$ ): 21.17 (C-31); 36.02 (C-18); 55.74 (C-4); 126.38 (C-22); 127.48 (C-8, C-10); 127.55 (C13, C-17); 128.18 (C-21, C-23); 128.40 (C-26, C-30); 128.65 (C-7, C-11); 129.23 (C-20, C-24); 129.38 (C-27, C-29); 129.85 (C-14, C-16); 132.48 (C-25); 133.99 (C-15); 137.88 (C-6); 138.31 (C-28); 140.58 (C-19); 143.36 (C-12); 143.96 (C-9); 164.79 (C-2); 197.54 (C-5).

RP-HPLC ( $\left.\mathrm{CH}_{2} \mathrm{OH}: \mathrm{H}_{2} \mathrm{O}=60: 40,1 \mathrm{~mL} / \mathrm{min}, 250 \mathrm{~nm}\right)$ : purity $=91.49 \% ; \quad t=4.78 \mathrm{~min}$.

Anal. (\%): Calcd. for $\mathrm{C}_{20} \mathrm{H}_{25} \mathrm{NO}_{4} \mathrm{~S}(483.58 \mathrm{~g} / \mathrm{mol}): \mathrm{C}, 72.03$; $H, 5.21 ; N, 2.90 ; S, 6.63$. Found: C, 72.08; H, 5.19; N, 2.90; S, 6.65 .

Synthesis of 4-benzyl-2-[4-(phenylsulfonyl)phenyl]-5-ptolyloxazole 7

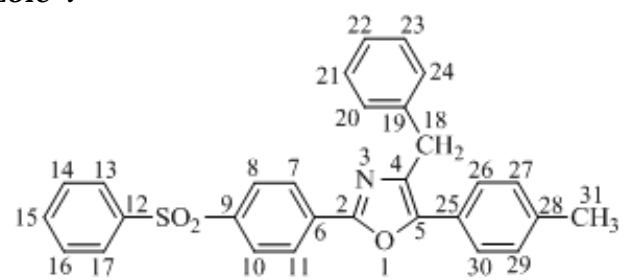

Fig. 4. Structure of compound 7 with atom numbering (for NMR assignments)
The crude $N$-(1-oxo-3-phenyl-1-p-tolylpropan-2-yl)-4(phenylsulfonyl) benzamide $6(4.84 \mathrm{~g}, 10 \mathrm{mmol})$ in $20 \mathrm{~mL}$ phosphoryl trichloride $(217.83 \mathrm{mmol}$ ) was heated under reflux for $4 \mathrm{~h}$. The excess of phosphorus oxychloride was removed under vacuum. After cooling, the oily residue was treated with a mixture of ice-water and extracted twice with $20 \mathrm{~mL}$ dichloromethane. The organic layers were combined and washed several times with $5 \%$ sodium hydrogen carbonate solution, then with water and dried over $\mathrm{Na}_{2} \mathrm{SO}_{4}$. After evaporation of the solvent, the crude product was recrystallized from ethanol as colourless crystals; yield $=92 \%(4.28 \mathrm{~g}) ; \mathrm{m} . \mathrm{p} .=191-193^{\circ} \mathrm{C}$.

UV-Vis $\left(\mathrm{CH}_{3} \mathrm{OH}, \lambda \mathrm{nm}\right)(\mathrm{lg} \varepsilon): 203.5$ (4.48); 245.8 (4.06); 338.3 (4.08).

FT-IR (KBr, $\left.v \mathrm{~cm}^{-1}\right): 3083 \mathrm{w} ; 3063 \mathrm{~m} ; 3026 \mathrm{~m} ; 2919 \mathrm{~m}$; 2855w; 1596s; 1510s; 1495m; 1483m; 1446s; 1322vs; 1310s; 1291s; 1158vs; 1091s; $846 \mathrm{~m}$.

${ }^{1} \mathrm{H}-\mathrm{NMR}\left(\mathrm{CDCl}{ }_{3}, \delta \mathrm{ppm}, J \mathrm{~Hz}\right): 2.33(\mathrm{~s}, 3 \mathrm{H}, \mathrm{H}-31) ; 4.13(\mathrm{~s}$, $2 \mathrm{H}, \mathrm{H}-18) ; 7.16(\mathrm{~m}, 1 \mathrm{H}, \mathrm{H}-22) ; 7.22(\mathrm{~d}, 7.7,2 \mathrm{H}, \mathrm{H}-27, \mathrm{H}-$ 29); 7.26 (m, 4H, H-20, H-21, H-23, H-24); 7.46 (bt, 8.4, 2H, $\mathrm{H}-14, \mathrm{H}-16) ; 7.47$ (d, 7.7, 2H, H-26, H-30); 7.53 (tt, 8.4, 1.6, $1 \mathrm{H}, \mathrm{H}-15) ; 7.91$ (dd, 8.4, 1.6, 2H, H-13, H-17); 7.95 (d, 8.6, $2 \mathrm{H}, \mathrm{H}-7, \mathrm{H}-11) ; 8.15$ (d, 8.6, 2H, H-8, H-10).

${ }^{13} \mathrm{C}-\mathrm{NMR}$ (CDCl,$\delta \mathrm{ppm}$ ): 21.43 (C-31); 33.13 (C-18); 125.50 (C-6); 125.91 (C-26, C-30); 126.98 (C-8, C-10, C22); 127.79 (C-13, C-17); 128.48 (C-7, C-11, C-21, C-23); 128.71 (C-27, C-29); 129.48 (C-14, C-16); 129.76 (C-20, C24); 131.81 (C-25); 133.47 (C-15); 136.06 (C-28); 138.48 (C-19); 138.82 (C-4); 141.47 (C-12); 142.48 (C-9); 148.10 (C-5); 157.82 (C-2).

RP-HPLC $\left(\mathrm{CH}_{3} \mathrm{OH}: \mathrm{H}_{2} \mathrm{O}=70: 30,1 \mathrm{~mL} / \mathrm{min}, 335 \mathrm{~nm}\right)$ : purity $=93.31 \% ; t_{p}=4.78 \mathrm{~min}$.

Anal. (\%): Calcd. for $\mathrm{C}_{29} \mathrm{H}_{23} \mathrm{NO}_{3} \mathrm{~S}(465.56 \mathrm{~g} / \mathrm{mol}): \mathrm{C}, 74.81$; $H, 4.98 ; N, 3.01 ; S, 6.89$. Found: $C^{2}, 74.77 ; H, 4.99 ; N, 3.01 ; S$, 6.87.

\section{Cytoxicity evaluation}

The biological determination was performed on Daphnia magna using a protocol previously described [42-44], with some modifications. Briefly, young daphnids were exposed to each compound in six concentrations varying from 1.1 to $23 \mu \mathrm{g} / \mathrm{mL}$ for $72 \mathrm{~h}$. The experiment was carried out in duplicate and phenylalanine and compound 1 were used as positive controls, whereas $1 \%$ dimethyl sulfoxide was used as negative control. The bioassay was performed under constant temperature and light conditions (at $25 \pm$ $1{ }^{\circ} \mathrm{C}$, in the dark) using a Sanyo MLR-351 H, USA climatic chamber.

The lethality was registered at 24,48 and $72 \mathrm{~h}$ and the lethality curves were plotted using the logarithm of concentrations against lethality percentage, $L(\%)$. Also, the prediction of $\mathrm{LC}^{\mathrm{C}} \mathrm{H}_{48 \mathrm{~h}}$ was performed using the GUSAR software application.

\section{Results and discussion \\ Chemistry}

In light of the biological and therapeutic importance presented above, there is considerable interest to obtain new heterocycles from 1,3-oxazol-5(4H)-one and 1,3oxazole class, and their acyclic intermediates using the reaction scheme 1 . The key precursor, 4-(phenylsulfonyl) benzoic acid 1, and corresponding acyl chloride $\mathbf{2}$ were previously reported in the literature [45, 46]. The compound 1 was synthesized by Friedel-Crafts reaction between benzene and 4-methylbenzenesulfonyl chloride in the presence of anhydrous aluminium chloride, followed by oxidation of 1-methyl-4-(phenylsulfonyl) benzene with chromium trioxide in glacial acetic acid, both reactions being carried out at reflux [45]. Then, the carboxylic acid 1 
was converted by reaction with thionyl dichloride into 4 (phenylsulfonyl)benzoyl chloride 2 [16], which was used without further purification for $\mathrm{N}$-acylating phenylalanine according to Steiger procedure by a nucleophilic substitution reaction in order to obtain new 3-phenyl-2-[4(phenylsulfonyl) benzamido]propanoic acid $\mathbf{3}$.

The intramolecular cyclodehydration of the acyclic intermediate $\mathbf{3}$ using ethyl chloroformate in the presence of $\mathrm{N}$-methylmorpholine in dichloromethane at room temperature yielded to new 4-benzyl-2-[4-(phenylsulfonyl) phenyl] oxazol-5(4H)-one 4 . The cyclization in basic medium may be considered to occur in accordance with the similar reaction mechanism which we formerly indicated in the literature for other saturated 2,4disubstituted 1,3-oxazol-5(4H)-one [16].

The reaction of $N$-acyl- $\alpha$-amino acid 3 with excess of thionyl dichloride was also carried out, by heating under reflux, to the new 3-phenyl-2-[4-(phenylsulfonyl) benzamido]propanoyl chloride 5 by the nucleophilic substitution mechanism proposed below (scheme 2). In the first step, the hydroxy group of precursor 3 is activated by conversion into a slightly displaceable chlorosulfonic group, - $\mathrm{OSOC1}$, with the formation of unstable ester I. In the next step, the nucleophilic attack of the chloride anion to the carbon atom of the ester functional group give an intermediate II, in which the attacked carbon has tetrahedral symmetry. In the last step, the chlorosulfonic group is eliminated from II as chloride anion and sulfur dioxide. In this way, the $\mathrm{N}$-acyl- $\alpha$-amino acyl chloride $\mathbf{5}$ is formed in pure state and with excellent reaction yield since are eliminated volatile by-products (hydrochloric acid, sulfur dioxide), which are easily removed from the reaction medium.

The Friedel-Crafts acylation of anhydrous toluene (used in a large excess both as reactant and solvent) with saturated 1,3-oxazol-5(4H)-one 4 in the presence of anhydrous aluminium chloride at room temperature led to new $N$-(1-oxo-3-phenyl-1-p-tolylpropan-2-yl)-4-(phenylsulfonyl)benzamide $\mathbf{6}$. The Lewis acid-mediated ring opening of 2-oxazolin-5-one $\mathbf{4}$ is possible because the saturated azlactones have a structure similar to that of the carboxylic acid anhydrides. The proposed mechanism for this electrophilic aromatic substitution is described in the previously our article [33]. An advantage of this reaction constitutes the fact that due to the electron-withdrawing through resonance and inductive electronic effects of the ketonic carbonyl group, the $C$-acylation product 6 is always less reactive than the heterocyclic precursor $\mathbf{4}$, so that multiple acylations do not take place.

The 1,3,4-trisubstituted 2-aza-1,4-butanedione 6 was also synthesized by $\mathrm{AlCl}_{\text {- }}$-catalysed acylation of anhydrous toluene with compound $\mathbf{5}$. In this case, the reaction yield was lower, which proves that saturated 1,3-oxazol-5(4H)ones are better $C$-acylation agents than $N$-acyl- $\alpha$-amino acyl chlorides.

Subsequently, by Robinson-Gabriel cyclization of 2-aza3-benzyl-1-[4-(phenylsulfonyl) phenyl]-4- -tolyl-1,4butanedione 6 using excess of phosphoryl trichloride at reflux, the new 4-benzyl-2-[4-(phenylsulfonyl) phenyl]-5-ptolyloxazole 7 was produced in very good yield. The proposed reaction mechanism for obtaining of 2,4,5trisubstituted 1,3-oxazole derivatives from $N$-acyl- $\alpha$-amino ketones in the presence of $\mathrm{POCl}_{3}$ is presented by us in the recent literature [15].

The chemical structures of the new compounds were established unequivocally by spectral techniques (UV-Vis, IR, MS, ${ }^{1 H}$-NMR, $\left.{ }^{13} \mathrm{C}-N M R\right)$, and elemental analysis.

\section{UV-Vis Spectral Data}

Generally, the electronic absorption spectra of the new compounds presented a sharp band at ë between 202.6$203.5 \mathrm{~nm}$ ( $E$ band) and an absorption maximum in the range $244.1-250.2 \mathrm{~nm}$ ( $B$ band). In addition, the UV spectrum of the new 1,3-oxazole 7 show a third intense absorption band at longer wavelength $(\lambda=338.3 \mathrm{~nm})$ compared with those of acyclic precursor 6 , due to extending of conjugation by formation of oxazole chromophore.

\section{IR Spectral Data}

In order to confirm the structure of newly synthesized compounds 3-7, the assignments of the infrared vibrational frequencies provide useful information. Thus, acyclic intermediates: $N$-acyl- $\alpha$-amino acid $\mathbf{3}$ and $N$-acyl- $\alpha$-amino ketone 6 exhibited the following characteristic absorption bands at wavenumbers: $3348 \mathrm{~cm}^{-1}$ and $3357 \mathrm{~cm}^{-1}$, respectively, for $\mathrm{N}-\mathrm{H}$ stretching vibration, $v(\mathrm{~N}-\mathrm{H})$, at 1748 $\mathrm{cm}^{-1}$ and $1670 \mathrm{~cm}^{-1}$, respectively, due to carbonyl stretching vibration, $v(O=C-C)$, and at $1642 \mathrm{~cm}^{-1}$ and $1652 \mathrm{~cm}^{-1}$, respectively, due to amidic carbonyl group absorption, $v(\mathrm{O}=\mathrm{C}-\mathrm{N})$ (amide I band). Characteristic of compounds 3 and $\mathbf{6}$ is also the amide II band, assigned to deformation vibration of $\mathrm{N}-\mathrm{H}$ group, $\delta(\mathrm{N}-\mathrm{H})$, present at $1540 \mathrm{~cm}^{-1}$ and $1533 \mathrm{~cm}^{-1}$, respectively. In both compounds ( 3 and 6 ), the amide III absorption band due to the C-N stretching vibration, $v(\mathrm{C}-\mathrm{N})$, and in compound $\mathbf{3}$, the absorption band attributed to the $\mathrm{C}-\mathrm{O}$ stretching vibration, í(C-O), overlap the absorption bands due to antisymmetric stretching vibration of the sulfonyl group, $\mathrm{v}_{\mathrm{as}}\left(\mathrm{SO}_{2}\right)$. In addition, for hydrogen-bonded dimer of compound $\mathbf{3}$, the absorption band due to stretching vibration of the $\mathrm{O}-\mathrm{H}$ bond, $\mathrm{v}(\mathrm{O}-\mathrm{H})$, appears in the first region of the IR spectrum and is strong, and very broad, extending from $2500 \mathrm{~cm}^{-1}$ to $3300 \mathrm{~cm}^{-1}$. This peak overlaps the sharper $\mathrm{C}-\mathrm{H}$ stretching peaks, which are extending beyond the $\mathrm{O}-\mathrm{H}$ envelope. The five broad
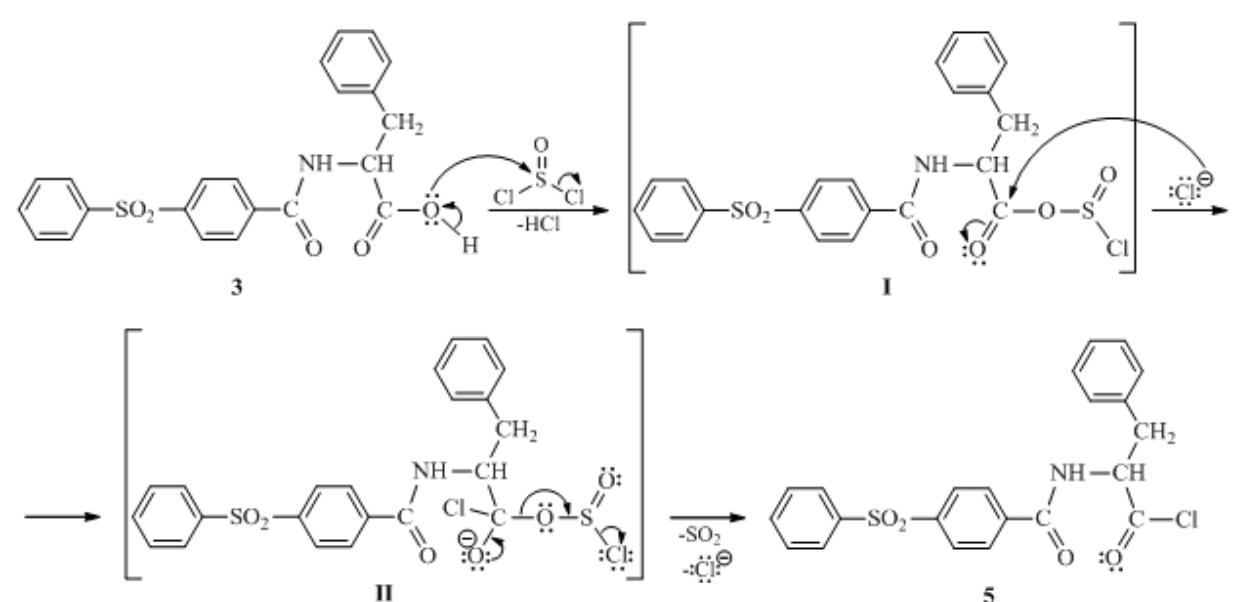

Scheme 2. Reaction mechanism proposed for obtaining of $N$-acyl- $\alpha$ amino acyl chloride 5 from $\mathrm{N}$-acyl$\alpha$-amino acid 3 
bands of medium intensity occurring in the range 2587-

$2792 \mathrm{~cm}^{-1}$ are also characteristic for the dimer.

The reaction between the $\mathrm{N}$-acyl- $\alpha$-amino acid $\mathbf{3}$ and thionyl dichloride is confirmed by the appearance in the IR spectrum of the reaction product, $N$-acyl- $\alpha$-amino acid chloride 5 , of two strong absorption bands as a doublet due to carbonyl (from chlorocarbonyl group) stretching vibration, $v(\mathrm{O}=\mathrm{C}-\mathrm{Cl})$ at characteristically high wavenumbers values: an absorption band at $1823 \mathrm{~cm}^{-1}$ attributed to fundamental vibration and a peak called Fermi resonance band at $1794 \mathrm{~cm}^{-1}$ due to overtone vibration, assigned to the Fermi resonance phenomenon. The medium absorption band due to the stretching vibration of the $\mathrm{C}-\mathrm{Cl}$ bond from the $\mathrm{COCl}$ fragment, $(\mathrm{C}-\mathrm{Cl})$, is also present at a larger wavenumber than usual, namely at $890 \mathrm{~cm}^{-1}$. By coupling between this vibration and the $\mathrm{C}=0$ fundamental vibration (from $1823 \mathrm{~cm}^{-1}$ ), the Fermi resonance band appears (at $1794 \mathrm{~cm}^{-1}$ ).

In the IR spectra of heterocycles $\mathbf{4}$ and $\mathbf{7}$ are present absorption bands at different characteristic values of wavenumbers compared with those of corresponding acyclic precursors $\mathbf{3}$ and $\mathbf{6}$, respectively, which confirms that cyclizations took place. Thus, in the IR spectrum of saturated azlactone 4 , the very strong absorption band due to the $\mathrm{C}=0$ valence vibration is shifted at $1823 \mathrm{~cm}^{-1}$, and the $v(\mathrm{~N}-\mathrm{H}), v(\mathrm{O}-\mathrm{H}), v(\mathrm{O}=\mathrm{C}-\mathrm{N})$, and $\delta(\mathrm{N}-\mathrm{H})$ absorption bands which are characteristic for acyclic precursor 3 were not presented. Also, for 4-benzyl-2,5-diaryl-1,3-oxazole 7 no signals were recorded in the $\mathrm{N}-\mathrm{H}$ and $\mathrm{C}=0$ regions. The absorption peak at $1651 \mathrm{~cm}^{-1}$ and $1596 \mathrm{~cm}^{-1}$, respectively was assigned to the $\mathrm{C}=\mathrm{N}$ stretching vibration of compounds $\mathbf{4}$ and $\mathbf{7}$. The heterocycles 4 and $\mathbf{7}$ showed additional sharp bands at $1045 \mathrm{~cm}^{-1}$ (4) and at $1091 \mathrm{~cm}^{-1}$ (7) due to $v_{\text {sym }}(\mathrm{C}-\mathrm{O}-\mathrm{C})$, which also confirmed the formation of the 1,3-0xazol-5(4H)-one and 1,3-oxazole ring, respectively. In these compounds, the $\mathrm{C}-\mathrm{O}-\mathrm{C}$ asymmetric absorption band is difficult to assign because it appears in the characteristic region for asymmetric sulfonyl stretch, $v_{\text {as }}\left(\mathrm{SO}_{2}\right)$.

\section{NMR Spectra}

The signals in ${ }^{1} \mathrm{H}-\mathrm{NMR}$ spectra are also in good agreement with the proposed chemical structures for the newly synthesized compounds. The assignment of the signals is based on the chemical shift and intensity pattern. Moreover, the 2D homonuclear connectivity ${ }^{1} \mathrm{H}-{ }^{-1} \mathrm{H}$ COSY experiments allowed univocal assignments.

The ${ }^{1} \mathrm{H}$-NMR spectra of the acyclic compounds 3 and $\mathbf{6}$ exhibited a doublet at a chemical shift of $8.98 \mathrm{ppm}$ and $9.20 \mathrm{ppm}$, respectively, attributed to secondary amide proton, which couples with $\mathrm{H}-4(3 \mathrm{~J}=8.2 \mathrm{~Hz})$.

The ${ }^{1} \mathrm{H}$-NMR spectra of heterocyclic compounds $\mathbf{4}$ and 7 comprise two characteristic sub-spectra: one of the 1,3oxazol-5(4H)-one and 1,3-oxazole ring, respectively, and one of the 4-(phenylsulfonyl)phenyl fragment. The signal assigned to the proton of the $\mathrm{NH}$ group from acyclic precursors $\mathbf{3}$ and $\mathbf{6}$ is absent in the ${ }^{1} \mathrm{H}$-NMR spectra of corresponding heterocycles 4 and 7 , respectively and this demonstrates that these new compounds have been obtained.

In the ${ }^{1} \mathrm{H}-\mathrm{NMR}$ spectra of the compounds $\mathbf{3}$ and $\mathbf{6}$, the signal of methine proton from C-4 appears as a doublet of doublets of doublets at $4.64 \mathrm{ppm}$ and $5.66 \mathrm{ppm}$, respectively, that results from coupling to the two nonequivalent protons of $\mathrm{CH}_{2}$ group and to the proton of $\mathrm{NH}$ group. For saturated azlactone 4, the $\mathrm{H}-4$ signal is observed at $4.72 \mathrm{ppm}$ as a doublet of doublets due the coupling to both nonequivalent protons of $\mathrm{CH}_{2}$ group from benzyl substituent in 4-position, that are maintained after cyclization. The signal exhibited by $\mathrm{H}-4$ in the ${ }^{\mathrm{H}} \mathrm{H}-\mathrm{NMR}$ spectrum of the compound $\mathbf{6}$, it is absent in the case of heterocyclic compound $\mathbf{7}$ and this is a proof that intramolecular cyclodehydration has occurred.

In addition, the two signals of nonequivalent protons from methylene group as doublet of doublets in the ${ }^{1} \mathrm{H}$ NMR spectrum of saturated azlactone 4 showed discernible downfield shifts of $0.14 \mathrm{ppm}$ and $0.17 \mathrm{ppm}$, relative to $\mathrm{CH}_{2}$ protons signals from the acyclic precursor 3 spectrum, due to the stronger deshielding effect of oxazolone ring compared to that of the $\mathrm{COOH}$ and $\mathrm{CONH}$ groups from compound $\mathbf{3}$.

Also, a further evidence of formation of the 1,3-oxazole 7 is provided the fact that ${ }^{1} \mathrm{H}-\mathrm{NMR}$ spectrum revealed a downfield shift of the signal attributed to the two protons $(\mathrm{H}-18)$ of the $\mathrm{CH}_{2}$ group as a singlet (because in this case the two protons of $\mathrm{CH}_{2}$ group are magnetically equivalent) at $\delta=4.13 \mathrm{ppm}$ compared to the two signals as a doublet of doublets (because of germinal coupling between nonequivalent protons of $\mathrm{CH}_{2}$ group with ${ }^{2} \mathrm{~J}=14.0 \mathrm{~Hz}$ and of vicinal coupling of these protons with $\mathrm{H}-4$ with ${ }^{3} \mathrm{~J}=9.9$ $\mathrm{Hz}$ and $4.7 \mathrm{~Hz}$, respectively) at $\delta$ values of $3.01 \mathrm{ppm}$ and $3.19 \mathrm{ppm}$ recorded for the $\mathrm{N}$-acyl- $\alpha$-amino ketone 6 . This fact is due to the stronger deshielding effect of oxazole ring (from 7) as against to that of the $\mathrm{C}=0$ and $\mathrm{CONH}$ groups from acyclic precursor 6 .

The obtaining of new compounds $\mathbf{3}, \mathbf{4 , 6}$ and $\mathbf{7}$ was further confirmed by the ${ }^{13} \mathrm{C}-\mathrm{NMR}$ spectra. In addition, the $2 \mathrm{D}$ heteronuclear connectivity ${ }^{1} \mathrm{H}-{ }^{13} \mathrm{C}$ HETCOR experiments substantially facilitated the unambiguous assignments of carbon atoms signals.

The carbon atom in position 4, which shows a signal at a chemical shift of $54.38 \mathrm{ppm}$ for $\mathrm{N}$-acyl- $\alpha$-amino acid $\mathbf{3}$ is shifted downfield with $12.41 \mathrm{ppm}$ after intramolecular cyclodehydration to 1,3-oxazol-5(4H)-one 4. Moreover, in the cyclization product 4 , the $\mathrm{C}-2$ resonated at $160.47 \mathrm{ppm}$ (being more shielded with $4.73 \mathrm{ppm}$ than carbon atom from CONH group of 3), and the C-5 at $176.73 \mathrm{ppm}$ (being shifted downfield with $3.86 \mathrm{ppm}$ than carbon atom from $\mathrm{COOH}$ group of intermediate 3 ).

In the ${ }^{13}$ C-NMR spectrum of 1,3-oxazole 7, the $C$-4 signal (at $\delta=138.82 \mathrm{ppm}$ ) is more deshielded with $83.08 \mathrm{ppm}$ by comparison of the signal of the same atom from $6(\delta=$ $55.74 \mathrm{ppm}$ ) and this confirmed that cyclization of the $\mathrm{N}$ acyl- $\alpha$-amino ketone $\mathbf{6}$ took place. It can be noticed the presence of the upfield signal attributed to the $\mathrm{C}-2$ at $\delta=$ $157.82 \mathrm{ppm}$ from the oxazole nucleus (7), while the signal assigned to carbon atom from amidic carbonyl group of intermediate 6 (at $164.79 \mathrm{ppm}$ ) is absent in the case of heterocyclic compound 7. Moreover, the C-5 atom from structure of 1,3-oxazole 7 resonated at $\delta=148.10 \mathrm{ppm}$, whereas the ketonic carbonyl carbon of the compound 6 resonated at $\delta=197.54 \mathrm{ppm}$ revealing an upfield shift for this carbon atom in the oxazole structure, which is a additional indication that the formation of oxazole ring took place.

\section{Mass Spectrum of $\mathbf{4}$}

Furthermore, additional support for the assigned structure of new compound $\mathbf{4}$ was obtained by recording the mass spectrum by GC-El-MS analysis. Only saturated 1,3-oxazol-5(4H)-one 4 could be analyzed due to the lower polarity, higher volatility and stability at high temperature compared to the other newly synthesized compounds. The molecular ion being very unstable does not show a signal in the mass spectrum. This begins to split at the level of oxazolone ring by eliminating a molecule of carbon dioxide, when cation-radical with $\mathrm{m} / \mathrm{z}=347$ (with relative 
abundance of $74.29 \%$ ) is formed. The base peak (PB) is cation-radical with $\mathrm{m} / \mathrm{z}=130$. And other main fragments that resulted under electron impact are indicated in experimental part.

\section{Cytotoxicity evaluation}

The results of biological determination are presented in table 1 and figure 5. All tested compounds exhibited under $20 \%$ lethality on the first $24 \mathrm{~h}$ of exposure, therefore no LC50 could be calculated. At $48 \mathrm{~h}$, with the exception of phenylalanine, all compounds exhibited moderate to high toxicity. The $\mathrm{LC}^{\mathrm{C}} \mathrm{H}_{48}$ was between 15.78 and $167.0 \mu \mathrm{g} /$ $\mathrm{mL}$. The $48 \mathrm{~h}$ increasing order of the tested compounds toxicity was: 4, 6, 3, 7 and $\mathbf{1}$. Phenylalanine induced a maximum of $10 \%$ lethality on daphnids at $48 \mathrm{~h}$. The increasing order of values obtained experimentally differs slightly from the order of those predicted with GUSAR software. Thus, with the exception of saturated azlactone 4 and phenylalanine, for which the predicted values are very different, in the case of new compounds $3, \mathbf{6}$ and $\mathbf{7}$ the predicted values are slightly lower, while for precursor 1 the predicted value is slightly higher. How ever, these values are comparable as magnitude order with experimental values obtained at $72 \mathrm{~h}$ of exposure.

At $72 \mathrm{~h}$, with the exception of phenylalanine all compounds exhibited high percentage of lethality at least to higher concentrations. Phenylalanine exhibited at the highest concentration lethality values between 20 and $40 \%$. The highest toxicity was induced by 1,3-oxazole 7, followed by compounds 3, 4 and $\mathbf{6}$. A much lower toxicity exhibited 1, with a LC50 ${ }_{72}$ of $11.76 \mu \mathrm{g} / \mathrm{mL}$, a concentration 7-fold higher than compound 7. In the same time, the toxicity of compound 1 did not vary significant from 48 to $72 \mathrm{~h}$. Thus, the higher differences between the results obtained at 48 and $72 \mathrm{~h}$ for $3,4,6$ and $\mathbf{7}$ could be due to structural changes in these newly synthesized compounds relative to precursor 1.

Table 1

RESULTS OF Daphnia magna BIOASSAY

\begin{tabular}{|c|c|c|c|c|c|}
\hline Compound & $\begin{array}{l}\text { Predicted } \\
\mathrm{LC50}_{45 \mathrm{~b}} \\
(\mu \mathrm{g} / \mathrm{mL})\end{array}$ & $\begin{array}{c}\text { Determined } \\
\mathrm{LC5}_{45} \mathrm{~b} \\
(\mu \mathrm{g} / \mathrm{mL})\end{array}$ & $\begin{array}{c}95 \% \mathrm{CI} \text { of } \\
\mathrm{LC5} 504 \mathrm{~h} \\
(\mu \mathrm{g} / \mathrm{mL})\end{array}$ & $\begin{array}{c}\text { Determined } \\
\text { LC5072 b } \\
(\mu \mathrm{g} / \mathrm{mL})\end{array}$ & $\begin{array}{l}95 \% \mathrm{CI} \text { of } \\
\mathrm{LC5} 0_{72} \mathrm{~b} \\
(\mu \mathrm{gg} / \mathrm{mL})\end{array}$ \\
\hline 3 & 7.66 & 34.01 & $17.34-66.71$ & 1.99 & $1.14-3.46$ \\
\hline 4 & 1.91 & 167.0 & $\mathrm{NC}$ & 3.37 & $1.92-5.90$ \\
\hline 6 & 0.54 & 37.67 & $15.34-92.50$ & 8.79 & $2.98-25.96$ \\
\hline 7 & 0.19 & 21.58 & $14.82-31.43$ & 1.59 & $1.52-16.62$ \\
\hline phenylalanine & 170.99 & $\mathrm{NC}$ & $\mathrm{NC}$ & $\mathrm{NC}$ & $\mathrm{NC}$ \\
\hline 1 & 68.19 & 15.78 & $8.79-28.28$ & 11.76 & $6.35-21.76$ \\
\hline
\end{tabular}

LC50 - 50\% lethal concentration; $95 \% \mathrm{CI}$ - $95 \%$ confidence interval; $\mathrm{NC}$ - not calculated due to the obtained results

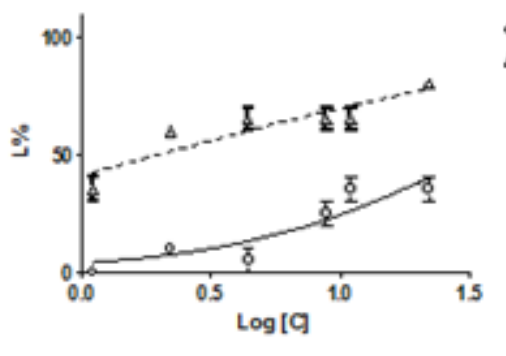

a

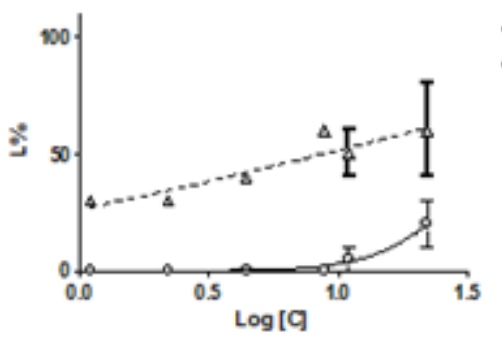

c

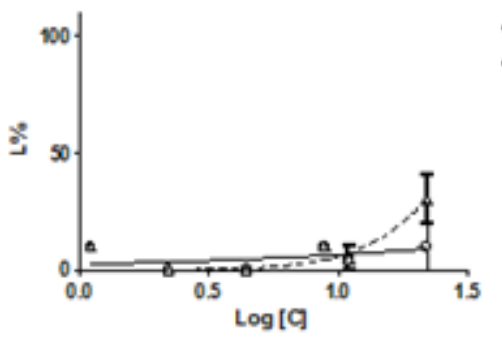

3799

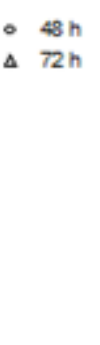

- $48 \mathrm{~h}$

$\Delta 72 h$

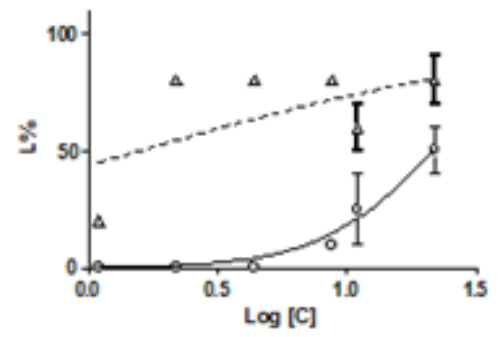

- $48 \mathrm{~h}$

$\Delta 72 \mathrm{~h}$

d

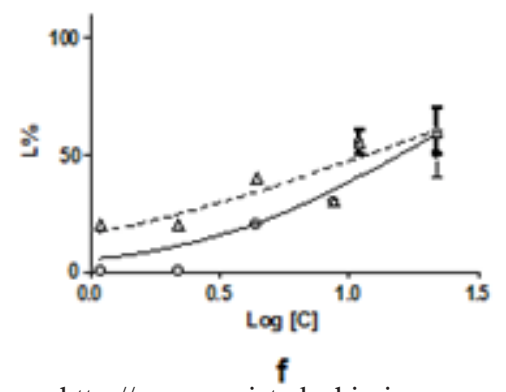

- $48 \mathrm{~h}$

$\Delta 72 \mathrm{~h}$ http://www.revistadechimie.ro

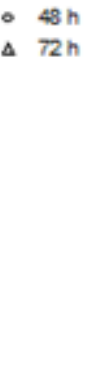

$48 \mathrm{~h}$

res
Fig. 5. Lethality curves on $D$. magna at 48 and $72 \mathrm{~h}$ of exposure for tested compounds; $a-3, b-4, c-6, d-7$ $e$ - phenylalanine, $f-1$ 


\section{Conclusions}

Five new compounds from $N$-acyl- $\alpha$-amino acid, $N$-acyl$\alpha$-amino acid chloride, 1,3-oxazol-5(4H)-one, $N$-acyl-áamino ketone, and 1,3-oxazole class, which contain in the structure a 4-(phenylsulfonyl)phenyl moiety, were synthesized and characterized. The new saturated azlactone $\mathbf{4}$ has been obtained by the reaction of acyl chloride $\mathbf{2}$ with phenylalanine, followed by intramolecular cyclization of the new $\mathrm{N}$-acyl phenylalanine 3 . The precursor $\mathbf{3}$ was also converted in the corresponding new $N$-acyl- $\alpha$-amino acyl chloride 5 . The new $N$-acyl- $\alpha$-amino ketone 6 was synthesized by treatment of 2,4-disubstituted 1,3-oxazol-5(4H)-one $\mathbf{4}$ or $\mathbf{N}$-acyl phenylalanyl chloride $\mathbf{5}$ with anhydrous toluene under Friedel-Crafts reaction conditions. By $\mathrm{POCl}_{3}$-catalysed cyclodehydration of acyclic intermediate $\mathbf{6}$, the new 2,4,5-trisubstituted 1,3-oxazole 7 has been obtained. The chemical structures of all compounds were confirmed by different spectral methods, and elemental analysis.

The newly synthesized compounds $3,4,6,7$ have been investigated for their biological activity on Daphnia magna. All compounds exhibited cytotoxicity, the effect being dependent of the exposure period. The 1,3-oxazole 7 showed the highest toxicity, comparable with the prediction performed using GUSAR software. However, further studies are needed in order to investigate the mechanism of action and the therapeutic potential of the new compounds.

\section{References}

1. TILVI, S., SINGH, K. S., Curr. Org. Chem., 20, no. 8, 2016, p. 898.

2. (a) LA REGINA, G., COLUCCIA, A., NACCARATO, V., SILVESTRI, R., Eur. J. Pharm. Sci., 131, 2019, p. 58. (b) GOGINENI, V., HAMANN, M. T., Biochim. Biophys. Acta Gen. Subj., 1862, no. 1, 2018, p. 81.

3. (a) LI, Q., SEIPLE, I. B., Tetrahedron, 75, no. 24, 2019, p. 3309. (b) OSTERMAN, I. A., KHABIBULLINA, N. F., KOMAROVA, E. S., KASATSKY, P., KARTSEV, V. G., BOGDANOV, A. A., DONTSOVA, O. A., KONEVEGA, A. L., SERGIEV, P. V., POLIKANOV, Y. S., Nucleic Acids Res., 45, no. 12, 2017, p. 7507.

4. KOLUPAEVA, V., Biochim. Biophys. Acta Mol. Cell Res., 1866, no. 1, 2019, p. 83.

5. SWAIN, S. S., PAIDESETTY, S. K., PADHY, R. N., Biomed. Pharmacother., 90, 2017, p. 760.

6. GIDDENS, A. C., BOSHOFF, H. I. M., FRANZBLAU, S. G., BARRY, III, C. E., COPP, B. R., Tetrahedron Lett., 46, no. 43, 2005, p. 7355.

7. RAINSFORD, K. D., OMAR, H., ASHRAF, A., HEWSON, A. T., BUNNING, R. A. D., RISHIRAJ, R., SHEPHERD, P., SEABROOK, R. W., InflammoPharmacology, 10, no. 3, 2002, p. 185.

8. (a) MIRZA, A. Z., ALTHAGAFI, I. I., SHAMSHAD, H., Eur. J. Med. Chem., 166, 2019, p. 502. (b) MASSARO, M., SCODITTI, E., PELLEGRINO, M., CARLUCCIO, M. A., CALABRISO, N., WABITSCH, M., STORELLI, C., WRIGHT, M., DE CATERINA, R., Pharmacol. Res., 107, 2016, p. 125. 9. SIM, A. K., MCCRAW, A. P., CAPRINO, L., ANTONETTI, F., MARTELLI, F., MORELLI, L., Thromb. Res., 32, no. 5, 1983, p. 479.

10. TAZEHKAND, A. P., AKBARZADEH, M., VELAIE, K., SADEGHI, M. R., SAMADI, N., Biomed. Pharmacother., 103, 2018, p. 755.

11. VELLUTI, F., MOSCONI, N., ACEVEDO, A., BORTHAGARAY, G., CASTIGLIONI, J., FACCIO, R., BACK, D. F., MOYNA, G., RIZZOTTO, M., TORRE, M. H., J. Inorg. Biochem., 141, 2014, p. 58.

12. (a) SUDO, R. T., DO CARMO, P. L., TRACHEZ, M. M., ZAPATA SUDO, G., Basic Clin. Pharmacol. Toxicol., 102, no. 3, 2008, p. 308. (b) DHILLON, D. S., PONG, S. F., MOOREHEAD, T. J., Drug Dev. Res., 25, no. 2, 1992, p. 161.

13. (a) BALA, S., SAINI, M., KAMBOJ, S., Int. J. ChemTech Res., 3, no. 3, 2011, p. 1102. (b) PINTO, I. L., WEST, A., DEBOUCK, C. M., DILELLA, A. G., GORNIAK, J. G., O'DONNELL, K. C., O'SHANNESSY, D. J., PATEL, A., JARVEST, R. L., Bioorg. \& Med. Chem. Lett., 6, no. 20, 1996, p. 2467.
14. BUDEANU, C., IVAS, E., SUNEL, V., Rev. Chim. (Bucharest), 32, no. 5, 1981, p. 454.

15. APOSTOL, T.V., BARBUCEANU, S.F., OLARU, O. T., DRAGHICI, C., SARAMET, G., SOCEA, B., ENACHE, C., SOCEA, L.-I., Rev. Chim. (Bucharest), 70, no. 4, 2019, p. 1099.

16. APOSTOL, T.V., DRAGHICI, C., DINU, M., BARBUCEANU, S.F., SOCEA, L. I., SARAMET, I., Rev. Chim. (Bucharest), 62, no. 2, 2011, p. 142.

17. CAZZOLA, M., CALZETTA, L., PAGE, C., ROGLIANI, P., MATERA, M. G., Trends Pharmacol. Sci., 40, no. 7, 2019, p. 452.

18. EZERINA, D., TAKANO, Y., HANAOKA, K., URANO, Y., DICK, T. P., Cell Chem. Biol., 25, no. 4, 2018, p. 447.

19. (a) ABDELRADY, H., HATHOUT, R. M., OSMAN, R., SALEEM, I., MORTADA, N. D., Eur. J. Pharm. Sci., 133, 2019, p. 115. (b) JIANG, Y., LI, X., HOU, J., HUANG, Y., WANG, X., JIA, Y., WANG, Q., XU, W., ZHANG, J., ZHANG, Y., Eur. J. Med. Chem., 143, 2018, p. 334. (c) WOOD, G. S., WU, J., Dermatol. Clin., 33, no. 4, 2015, p. 747. (d) UWAI, Y., IWAMOTO, K., Drug Metab. Pharmacokinet., 25, no. 2, 2010, p. 163.

20. WONG, D., TSAI, P. N. W., IP, K. Y., IRWIN, M. G., Best Pract. Res. Clin. Anaesthesiol., 32, no. 2, 2018, p. 223.

21. ARGYRIDIS, S., Obstet. Gynecol. Reprod. Med., 29, no. 4, 2019, p. 118.

22. JADHAV, A. P., SADAKA, F. G., Am. J. Emerg. Med., 37, no. 6, 2019, p. 1169.

23. SHARMA, P., SINGH, S., SIDDIQUI, T. I., SINGH, V. S., KUNDU, B., PRATHIPATI, P., SAXENA, A. K., DIKSHIT, D. K., RASTOGI, L., DIXIT, C., GUPTA, M. B., PATNAIK, G. K., DIKSHIT, M., Eur. J. Med. Chem., 42, no. 3, 2007, p. 386.

24. (a) SCHAPER, A., EBBECKE, M., Eur. J. Intern. Med., 45, 2017, p. 66. (b) CAI, Z., LOU, Q., WANG, F., LI, E., SUN, J., FANG, H., XI, J., JU, L., Int. J. Clin. Exp. Pathol., 8, no. 7, 2015, p. 8655.

25. (a) OGWANG, S., NGUYEN, H. T., SHERMAN, M., BAJ AKSOUZIAN, S., JACOS, M. R., BOOM, W. H., ZHANG, G.-F., NGUYEN, L., J. Biol. Chem., 286, no. 17, 2011, p. 15377. (b) KRAUT, J. A., Am. J. Kidney Dis., 68, no. 1, 2016, p. 161.

26. FEAR, G., KOMARNYTSKY, S., RASKIN, I., Pharmacol. Ther., 113, no. 2, 2007, p. 354.

27. DENG, H., BANNISTER, T. D., JIN, L., BABINE, R. E., QUINN, J., NAGAFUJI, P., CELATKA, C. A., LIN, J., LAZAROVA, T. I., RYNKIEWICZ, M. J., BIBBINS, F., PANDEY, P., GORGA, J., MEYERS, H. V., ABDELMEGUID, S. S., STRICKLER, J. E., Bioorg. Med. Chem. Lett., 16, no. 11, 2006, p. 3049.

28. SEMPLE, G., ASHWORTH, D. M., BATT, A. R., BAXTER, A. J., BENZIES, D. W. M., ELLIOT, L. H., EVANS, D. M., FRANKLIN, R. J., HUDSON, P., JENKINS, P. D., PITT, G. R., ROOKER, D. P., YAMAMOTO, S., ISOMURA, Y., Bioorg. Med. Chem. Lett., 8, no. 8, 1998, p. 959.

29. (a) BERA, S., MONDAL, D., Bioorg. Med. Chem., 27, no. 13, 2019, p. 2689. (b) MISHRA, M., MISHRA, V. K., KASHAW, V., IYER, A. K., KASHAW, S. K., Eur. J. Med. Chem., 125, 2017, p. 1300. (c) NOORDEEN, S. K., Clin. Dermatol., 34, no. 1, 2016, p. 32. (d) AHMAD, I., SHAGUFTA, Int. J. Pharm. Pharm. Sci., 7, no. 3, 2015, p. 19. (e) MADY, M. F., AWAD, G. E. A., JORGENSEN, K. B., Eur. J. Med. Chem., 84, 2014, p. 433. (f) PEZZELLA, A. T., FANG, W., Curr. Probl. Surg., 45, no. 10, 2008, p. 675. 30. BARBUCEANU, S. F., SOCEA, L. I., DRAGHICI, C., PAHONTU, E. M., APOSTOL, T. V., BARBUCEANU, F., Rev. Chim. (Bucharest), 68, no. 10, 2017, p. 2436.

31. BARBUCEANU, S.F., SARAMET, G., BANCESCU, G., DRAGHICI, C., APOSTOL, T.-V., TARAN, L., DINU-PIRVU, C. E., Rev. Chim. (Bucharest), 64, no. 4, 2013, p. 355.

32. BARBUCEANU, S.F., BANCESCU, G., DRAGHICI, C., BARBUCEANU, F., CRETU, O. D., APOSTOL, T. V., BANCESCU, A., Rev. Chim. (Bucharest), 63, no. 4, 2012, p. 362.

33. APOSTOL, T.V., SARAMET, I., DRAGHICl, C., BARBUCEANU, S.F., SOCEA, L. I., ALMAJAN, G. L., Rev. Chim. (Bucharest), 62, no. 5, 2011, p. 486.

34. BARBUCEANU, S. F., OLARU, O. T., NITULESCU, G. M., DRAGHICl, C., SOCEA, L. I., BARBUCEANU, F., ENACHE, C., SARAMET, G., Rev. Chim. (Bucharest), 69, no. 9, 2018, p. 2346. 
35. SOCEA, L. I., VISAN, D. C., BARBUCEANU, S. F., APOSTOL, T. V., BRATU, O. G., SOCEA, B., Rev. Chim. (Bucharest), 69, no. 4, 2018, p. 795.

36. SOCEA, L. I., BARBUCEANU, S. F., SOCEA, B., DRAGHICI, C., APOSTOL, T. V., PAHONTU, E. M., OLARU, O. T., Rev. Chim. (Bucharest), 68, no. 11, 2017, p. 2503.

37. SOCEA, L.I., SOCEA, B., SARAMET, G., BARBUCEANU, S.-F., DRAGHICl, C., CONSTANTIN, V. D., OLARU, O. T., Rev. Chim. (Bucharest), 66, no. 8, 2015, p. 1122.

38. SOCEA, L.I., SARAMET, G., MIHALCEA, F., APOSTOL, T. V., ANDREESCU, C., DRAGHICl, C., SOCEA, B., Rev. Chim. (Bucharest), 65, no. 2, 2014, p. 156.

39. SOCEA, L. I., APOSTOL, T. V., SARAMET, G., BARBUCEANU, S. F., DRAGHICI, C., DINU, M., J. Serb. Chem. Soc., 77, no. 11, 2012, p. 1541. 40. NITULESCU, G. M., DRAGHICI, C., CHIFIRIUC, M.-C., MISSIR, A.-V., Farmacia, 57, no. 5, 2009, p. 527.
41. NITULESCU, G. M., PAUNESCU, H., DRAGHICl, C., MISSIR, A.-V., COMAN, O. A., FULGA, I., Farmacia, 58, no. 2, 2010, p. 190.

42. BARBUCEANU, S.F., OLARU, O. T., SOCEA, L.I., DRAGHICI, C., SARAMET, G., BARAITAREANU, S., SOCEA, B., BARBUCEANU, F., Rev. Chim. (Bucharest), 70, no. 1, 2019, p. 13.

43. SOCEA, L. I., BARBUCEANU, S. F., ISCRULESCU, L., SOCEA, B., HRUBARU, M., PAHONTU, E. M., DIACONU, C. C., BRATU, O. G., OLARU, 0. T., Rev. Chim. (Bucharest), 69, no. 12, 2018, p. 3341.

44. NITULESCU, G., NICORESCU, I. M., OLARU, O. T., UNGURIANU, A., MIHAI, D. P., ZANFIRESCU, A., NITULESCU, G. M., MARGINA, D., Int. J. Mol. Sci., 18, no. 10, 2017, p. 2217.

45. MAVRODIN, A., ZOTTA, V., STROENESCU, V. M., OTELEANU, D., Pharm. Zentr. Dtschl., 95, no. 9, 1956, p. 353.

46. SCHIKETANZ, I., DRAGHICI, C., SARAMET, I., BALABAN, A. T., Rev. Roum. Chim.(Bucharest), 47, no. 3-4, 2002, p. 235.

Manuscript received: 6.08 .2019 